\title{
$\mathrm{AOM} / \mathrm{DSS}$ 유발 대장암에 대한 榆根皮와 白花蛇舌草 단일 및 배합 추출물의 항암 및 항염 효과
}

이선아, 백동기, 문 구

원광대학교 한의과대학 내과학교실

\section{Anti-neoplastic and Anti-inflammatory Effects of Single and Mixed Extracts of Ulmus Davidiana and Oldenlandia Diffusa on Azoxymethane/dextran Sodium Sulfate-induced Colonic Neoplasms}

\author{
Seon-a Lee, Dong-gi Baek, Goo Moon \\ Dept. of Internal Medicine, College of Korean Medicine, Wonkwang University
}

\begin{abstract}
Objectives: The aim of this experimental study was to evaluate the anti-neoplastic and anti-inflammatory effects of single and mixed extracts of Ulmus davidiana (UD) and Oldenlandia diffusa (OD) on azoxymethane/dextran sodium sulfate (AOM/DSS)-induced colonic neoplasms in mice.

Methods: AOM/DSS induces colitis-associated colonic neoplasms in mice. Mice were divided into seven groups: normal-no inducement and no treatment; control-colonic neoplasms with no treatment; UD-colonic neoplasms and treatment with UD: OD-colonic neoplasms and treatment with OD; UD1+OD1-colonic neoplasms and treatment with UD1 and OD1. UD1+OD2-colonic neoplasms and treatment with UD1 and OD2; UD2+OD1-colonic neoplasms and treatment with UD2 and OD1. Single and mixed preparations of UD and OD were applied to mice for six weeks. The colon length and weight and histopathologic changes of colon tissue were observed. Serum pro-inflammatory cytokines, including tumor necrosis factor-alpha (TNF-a) and interleukin-6 (IL-6), were determined by enzyme-linked immunosorbent assay. The mRNA expression levels of Bax, Bcl-2, and interferon-gamma (INF-y) were measured by RT-PCR.

Results: The colon length was significantly increased in OD, UD1+OD2, and UD2+OD1 mice, and the colon weight was significantly decreased in OD and UD1+OD2 mice. The morphological change of colon epithelial cells was more suppressed in complex-treatment groups than in single-treatment groups. The inhibitory effect on inflammatory cell invasion was especially shown in UD1+OD2 mice. The serum level of the pro-inflammatory TNF-a was decreased in all complex-treatment groups, and the IL-6 level was decreased in UD1+OD1 mice. Single-treatment groups had an increase in the mRNA expression of the pro-apoptosis regulator Bax, and UD2+OD1 decreased the mRNA expression of the anti-apoptosis regulator Bcl-2. The mRNA expression of INF-y associated with inflammation was decreased in OD and UD1+OD2 mice.

Conclusions: This study suggests that single and mixed extracts of Ulmus davidiana and Oldenlandia diffusa have anti-neoplastic and anti-inflammatory effects on AOM/DSS-induced colonic neoplasms in mice. Therefore, we conclude that UD, OD, and a mixture of UD and OD are potential therapeutic agents for colitis-associated colonic neoplasms.
\end{abstract}

Key words: colonic neoplasms, tumor necrosis factor-alpha, interleukin-6, apoptosis

· 투고일: 2017.08.31, 심사일: 2017.12.23, 게재확정일: 2017.12.27 · 교신저자: 문 구 전북 전주시 덕진구 덕진동 2가 142-1번지 원광대학교 전주한방병원 한방내과

TEL: 063-270-1114 FAX: 063-270-1594

E-mail: gmoon@wonkwang.ac.kr

. 이 논문은 2016년도 8월 원광대학교 일반대학원 한의학과 비 계내과학 박사학위 논문임.

\section{I. 서 론}

암의 치료요법 중 항암제는 주로 $\mathrm{DNA}$ 에 손상 을 초래하여 세포분열을 저해하거나 세포의 성장 을 막는 것인데, 이러한 대사경로는 암세포 뿐만이 
아니라 정상세포에서도 동일하기 때문에 정상조직 에도 독성을 일으키는 것이 불가피하다. 따라서 빈혈, 구토, 백혈구 감소, 모발 손상 등과 같은 부 작용을 야기하므로 ${ }^{2}$, 부작용도 줄이고 암세포를 효 과적으로 억제할 수 있는 천연물질을 개발하기 위 한 노력들이 진행되고 있다 ${ }^{3}$.

榆根皮(Ulmus davidiana)는 느릅나무과에 속하 는 落葉喬木인 느릅나무의 樹皮 또는 根皮를 건조 한 것으로 榆根白皮, 白榆皮, 榆皮, 零榆皮, 榆錢皮 라고도 하며 甘, 平, 無毒하고 利水通淋, 消腫解毒 등의 효능으로 癱疽發背, 風熱腫毒, 疥癬, 項生瘰痿 등을 치료한다. 유근피에 관한 연구로는 김 등 ${ }^{5}$ 이 유근피의 면역 기능 활성화를 통한 암 전이 억제 효과를, 한 등은 유근피 추출액이 간암세포의 고 사를 촉진시킴으로써 항암 효과를 나타낸다고 보 고하였다.

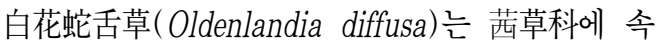
하는 1 년생 부수인 백운풀의 全草로 甘苦, 寒, 無毒 하고 胃 - 小腸 - 大腸經에 작용하며, 淸熱利濕, 消 瘔解毒, 抗癌 등의 효능이 있어 咽喉腫痛, 癱腫瘡 毒, 腸癰, 癌腫 등을 치료한다. 백화사설초에 관련 된 연구로는 이 등이 항암제와의 병용투여시 백화 사설초의 항암작용 상승효과를, 박 등 ${ }^{9}$ 이 백화사설 초의 세포자멸사 유도에 의한 위암세포주의 항암 효과를 보고하였다.

유근피와 백화사설초에 관한 각각의 생리 활성 연구는 상기와 같이 활발하게 이루어지고 있으나. 이 두 약재의 배합물이 가지는 항암 작용에 관해 서는 아직 보고되지 않은 바, 본 저자는 in vivo 실 험으로 유근피와 백화사설초의 단일 및 배합제제 의 항암 및 항염 효과를 알아보고자, $\mathrm{AOM} / \mathrm{DSS}$ 로 유발된 대장암 mice의 대장 길이 및 무게의 변화를 측정하고, 대장 조직의 병리학적 변화를 관찰하고, 염증매개인자인 TNF- $a$ 와 IL- 6 의 변화, RT-PCR 로 측정한 $\mathrm{Bax}, \mathrm{Bcl}-2, \mathrm{INF}-\gamma$ 의 발현도를 조사하 여 다음과 같은 결과를 얻었기에 보고하는 바이다.

\section{II. 실험재료 및 방법}

1. 재 료

1) 실험동물

체중이 약 28 30 g의 6주령 ICR계 mice(Samtako Bio Korea, 한국)를 실내온도 $22 \sim 24{ }^{\circ} \mathrm{C}$, 습도 $25 \sim 30 \%$ 의 항온항습 조건하에서 3 일 이상 실험실 환경에 적응시킨 후 실험에 사용하였으며, 적응기간 동안 에 고형사료(pellet, 삼양주식회사, 한국)와 물을 충 분히 공급하여 자유롭게 섭취하도록 하였다.

2) 약재 및 약물 조제

유근피(Ulmus davidiana, UD)와 백화사설초 (Oldenlandia diffusa, OD) 및 유근피와 백화사설 초의 배합물을 실험에 사용하였다. 유근피는 경상 북도 영주시에서, 백화사설초는 경상남도 산청군에 서 채취한 덕인제약 한국식의약연구소에서 검증된 것을 사용하였다.

유근피 $300 \mathrm{~g}$ 과 백화사설초 $300 \mathrm{~g}$ 을 증류수 1000 $\mathrm{ml}$ 에 넣어 전자식약탕기(대웅전기산업(주), 한국) 로 3시간 동안 전탕 추출하고 여과하였으며, 고속 원심분리기(Centrikon T-42K, Kontron instruments, Italy)를 이용하여 $3,000 \mathrm{rpm}$ 에서 15 분간 원심분리 하여 상층액을 취하였고, rotary evaporator(Buchi, Netherlands)로 수분을 증발시켜 전량이 $100 \mathrm{ml}$ 가 되도록 감압 농축하였으며, 농축된 검액을 동결건 조기(삼원주식회사, 한국)를 이용하여 $-80{ }^{\circ} \mathrm{C}$ 에서 동결 건조시켜 유근피 $17.5 \mathrm{~g}$ (수율: $5.83 \%$ )과 백화 사설초 $31 \mathrm{~g}$ (수율: 10.33\%)을 추출하였다.

2. 방 법

1) Azoxymethane/Dextran sulfate sodium으로 인한 대장암 유발

6주령 ICR계 mice에 Azoxymethane(AOM, Sigma, USA) $10 \mathrm{mg} / \mathrm{kg}$ 을 생리식염수에 용해하여 복강에 $5 \mathrm{ml} / \mathrm{kg}$ 용량으로 투여하고, $\mathrm{AOM}$ 투여 후 1주가 된 시점에 $2 \%$ Dextran sulfate sodium(DSS, Sigma, USA)을 음수에 용해시켜 1주간 투여하였다. 그리 
고 2 주간의 휴식기를 가진 후, $2 \% \mathrm{DSS}$ 를 1 주간 음수로 투여한 다음 다시 2 주간의 휴식기를 가지 게 하였다 ${ }^{10}$.

2) 실험군 설정 및 투여 용량

실험을 위하여 다음과 같이 군을 분류하였다. 정 상군(Normal, $n=6$ )은 대장암을 유발시키지 않고 아무처치를 시행하지 않았으며, 대조군(Control, $n=6$ ) 은 AOM/DSS로 대장암을 유발시킨 후 아무처치 를 시행하지 않았다. 단일실험군으로 유근피 투여 군(Ulmus davidiana, $\mathrm{UD}, \mathrm{n}=6$ ) 과 백화사설초 투 여군(Oldenlandia diffusa, OD, $\mathrm{n}=6$ )을 설정하였 고, 배합실험군으로 유근피:백화사설초 비율을 $1: 1$ 로 한 배합투여군(UD1+0D1, n=6), 유근피:백화 사설초 비율을 $1: 2$ 로 한 배합투여군(UD1+OD2, $\mathrm{n}=6)$, 유근피 : 백화사설초 비율을 $2: 1$ 로 한 배합투 여군(UD2+0D1, n=6)을 설정하였다.

유근피와 백화사설초의 성인 $70 \mathrm{~kg}$ 기준으로 1 일 투여량을 $4 \mathrm{~g}$ 으로 산정하였으며, 이를 본 연구 에서 추출한 분말 양으로 환산하였을 경우 유근피 는 $3.33 \mathrm{mg} / \mathrm{kg}$, 백화사설초는 $5.90 \mathrm{mg} / \mathrm{kg}$ 이었다. $\mathrm{AOM}$ 유발 1 주 후부터 유근피 투여군(UD)은 3.33 $\mathrm{mg} / \mathrm{kg}$, 백화사설초 투여군(OD)은 $5.90 \mathrm{mg} / \mathrm{kg}$, 유근피: 백화사설초 비율을 1:1로 한 배합투여군(UD1+OD1)은 $3.33+5.90 \mathrm{mg} / \mathrm{kg}$, 유근피:백화사설초 비율을 $1: 2$ 로 한 배합투여군(UD1+0D2)은 $3.33+11.8 \mathrm{mg} / \mathrm{kg}$, 유 근피:백화사설초 비율을 $2: 1$ 로 한 배합투여군 (UD2+0D1)은 $6.66+5.90 \mathrm{mg} / \mathrm{kg}$ 용량으로 음수에 약물을 혼합하여 6주간 투여하였다(Table 1).

Table 1. Distribution of Groups

\begin{tabular}{cl} 
Groups & \multicolumn{1}{c}{ Treatment } \\
\hline Normal & No inducement and no treatment \\
Control & AOM/DSS-induced colonic neoplasms and no treatment \\
UD & AOM/DSS-induced colonic neoplasms and treatment with UD $(3.33 \mathrm{mg} / \mathrm{kg})$ \\
OD & AOM/DSS-induced colonic neoplasms and treatment with OD $(5.90 \mathrm{mg} / \mathrm{kg})$ \\
UD1+OD1 & AOM/DSS-induced colonic neoplasms and treatment with UD $(3.33 \mathrm{mg} / \mathrm{kg})$ and OD $(5.90 \mathrm{mg} / \mathrm{kg})$ \\
UD1+OD2 & AOM/DSS-induced colonic neoplasms and treatment with UD $(3.33 \mathrm{mg} / \mathrm{kg})$ and OD $(11.8 \mathrm{mg} / \mathrm{kg})$ \\
UD2+OD1 & AOM/DSS-induced colonic neoplasms and treatment with UD $(6.66 \mathrm{mg} / \mathrm{kg})$ and OD $(5.90 \mathrm{mg} / \mathrm{kg})$ \\
\hline
\end{tabular}

3) 사망 및 임상증상 관찰

실험 동물은 약물 투여 및 실험 종료시간까지 사망 또는 빈사발생여부 및 증상을 관찰하였다.

4) 대장 길이 및 무게 측정

실험 종료 후 대장의 말단에서 맹장부분까지 절 제하여 적출한 대장의 길이를 자로 재어 측정하였 고, 대장의 무게를 저울을 이용하여 측정하였다.

5) 조직학적 관찰

실험 종료 후 mice의 복부를 절개 후 대장의 말 단에서 맹장부분까지 절제하여 적출한 후 맹장 아 래서 $1 \mathrm{~cm}$ 의 조직과 대장의 말단 부분에서 위로 $1 \mathrm{~cm}$ 의 조직을 절개하여 bouin solution에 고정시켰다.
고정된 조직은 파라핀 블록을 만들어 microtome으 로 $5 \mu \mathrm{m}$ 간격으로 잘라서 슬라이드 위에 놓은 다 음 $\mathrm{H} \& \mathrm{E}$ 염색 방법에 따라 염색하여 광학현미경 (Nikon Mokel 80i, Japan)으로 실험적 관찰에 사 용하였다.

6) ELISA에 의한 cytokine 측정

Tumor Necrosis Factor-alpha (TNF-a) 측정은 Rat TNF-a (Invitrogen, USA)를 사용하였고, Interleukin-6 (IL-6) 측정은 Rat IL-6(Invitrogen, USA)를 사용 하여 Spectramax(M2, Molecular Devices, USA)로 $450 \mathrm{~nm}$ 에서 Optical density를 측정하였다.

7) Total RNA 분리 및 Reverse Transcription 
Polymerase Chain Reaction(RT-PCR)

대장 부위의 조직 $(25 \mathrm{mg})$ 을 TRIZOL reagent ( $\mathrm{Gibco-BRL,} \mathrm{USA)로} \mathrm{균질화하고} \mathrm{얻은} \mathrm{RNA를}$ spectrophotometer(Eppendorf, Germany)를 사용하 여 $260 \mathrm{~nm}$ 에서 Optical density값을 읽어 RNA의 순도 및 농도를 정량하였다. 이들 대장 부위 조직의 total RNA는 사용시까지 $-70{ }^{\circ} \mathrm{C}$ 에서 보관하였다.

분리된 total RNA $5 \mu \mathrm{g}$ 을 RT premix(Bioneer, 한국)에 넣어 Mastercycler gradient(Eppendorf, Germany)를 이용하여 $\mathrm{cDNA}$ 를 합성하여 $\mathrm{PCR}$ 증폭 을 위한 template로 사용하였다. 이때 housekeeping 유전자인 glyceraldehyde-3-phosphate dehydrogenase (Gapdh)를 internal control로 사용하였다. 합성된 cDNA를 template로 PCR premix(Intron, 한국)에
넣어 Mastercycler gradient(Eppendorf, Germany) 를 이용하여 Bax, Bcl2, Interferon-gamma(INF-y) 유전자를 중합효소 연쇄 반응(Polymerase Chain Reaction, PCR) 방법으로 유전자 부위를 증폭하였 다.

이렇게 증폭된 $\mathrm{Bax}, \mathrm{Bcl} 2, \mathrm{INF}-\gamma$ 의 $\mathrm{DNA}$ 를 Greenview nucleic acid gel stain(I0 Rodeo, 1:10,000) 를 포함한 $1.5 \%$ agarose gel상에서 0.5x TBE buffer (80 mM Tris-HCL, $80 \mathrm{mM}$ boric acid, $2 \mathrm{mM}$ $\mathrm{EDTA}, \mathrm{pH}$ 8.3)로 $100 \mathrm{~V}$ 에서 전기 영동시켜 관찰 한 후 Image Station(Kodak, USA)을 이용하여 촬 영하였으며, Kodak MI Software(Kodak, USA)를 이용하여 측정하였다(Table 2).

Table 2. Sequence of Bax, Bcl-2 and INF-r in PCR

\begin{tabular}{cll}
\multirow{2}{*}{ GAPDH } & Forward sequence & 5'-ACTCCATCACCATCTTCCAG-3' \\
& Reverse sequence & 5'-CCTGCTTTCACCACCTCCTTG-3' \\
\hline \multirow{2}{*}{ Bax } & Forward sequence & 5'-CATCTTCTTCCAGATGGTGA-3' \\
& Reverse sequence & 5'-GTTTCATCCAGGATCGAGCAG-3' \\
\hline \multirow{2}{*}{ Bcl-2 } & Forward sequence & 5'-CGGTTCAGGTACTCAGTCAT-3' \\
& Reverse sequence & 5'-ACTTTGCACAGATGTCCAGT-3' \\
\multirow{2}{*}{ INF-> } & Forward sequence & 5'-AACGCTACACACTGCAATCTTGG-3' \\
& Reverse sequence & 5'-CTCGGATGAGCTCATTGAATGC-3' \\
\hline
\end{tabular}

3. 통계 처리

실험 성적은 평균값과 표준오차 $(m e a n \pm S . E$.$) 로$ 표시하였으며, Window용 SPSS(version 21, SPSS) 를 이용하여, 비모수적 방법 중 Mann-Whitney U test를 시행하여 실험군 간의 통계적 유의성을 관 찰하였다. 전체 실험의 통계적인 유의성은 신뢰구 간 $\mathrm{p}<0.05$ 에서 의미를 부여하였다.

\section{III. 결 과}

1. 대장의 길이 및 무게의 변화 측정

1) 대장 길이의 변화
대장 길이 변화를 관찰한 결과, Normal군은 $11.1 \pm$

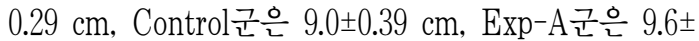

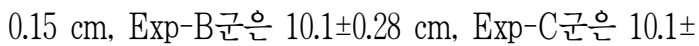
$0.44 \mathrm{~cm}, \mathrm{Exp}-\mathrm{D}$ 군은 $10.5 \pm 0.13 \mathrm{~cm}, \mathrm{Exp}-\mathrm{E}$ 군은 $10.5 \pm$ $0.20 \mathrm{~cm}$ 를 나타내었다. Normal군에 비하여 Control 군은 유의한 감소를 나타내었고, Control군에 비하 여 $\mathrm{Exp}-\mathrm{B}$ 군, $\mathrm{Exp}-\mathrm{D}$ 군, $\mathrm{Exp}-\mathrm{E}$ 군은 유의한 증가를 나타내었다(Fig. 1). 


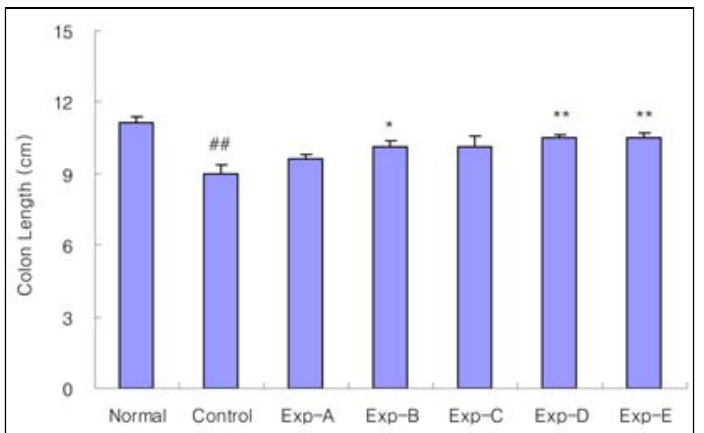

Fig. 1. Effect of UImus davidiana, Oldenlandia diffusa and their mixture on the colon length in AOM/DSS-induced colitis-associated colonic neoplasms mice.

Normal : no inducement and no treatment, Control : AOM/DSS-induced colon cancer and no treatment, Exp-A : AOM/DSS-induced colon cancer and treatment with UD, Exp-B : AOM/DSS-induced colon cancer and treatment with OD, Exp-C : AOM/DSS-induced colon cancer and treatment with UD 1 and OD 1. Exp-D : AOM/DSS-induced colon cancer and treatment with UD 1 and OD 2, Exp-E : A0M/DSS-induced colon cancer and treatment with UD 2 and OD 1

Results are shown as mean \pm S.E. \#\# $p<0.01$ compared with normal group

$* p<0.05, * * p<0.01$ compared with control group

2) 대장 무게의 변화

대장 무게 변화를 관찰한 결과, Normal군은 $607.8 \pm$ $31.5 \mathrm{mg}$, Control군은 705.8 $26.8 \mathrm{mg}$, Exp-A군은

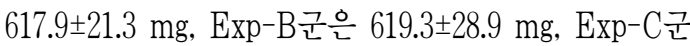

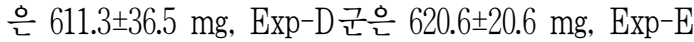
군은 $644.3 \pm 34.6 \mathrm{mg}$ 를 나타내었다. Normal군에 비 하여 Control군은 유의한 증가를 나타내었고, Control 군에 비하여 $\operatorname{Exp}-\mathrm{B}$ 군, $\mathrm{Exp}-\mathrm{D}$ 군은 유의한 감소를 나타내었다(Fig. 2).

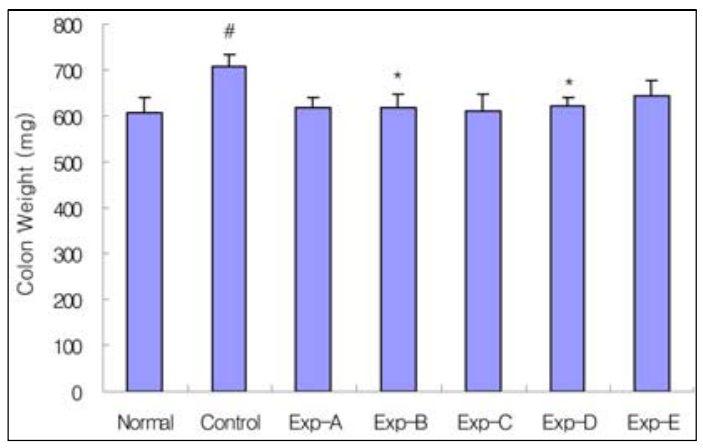

Fig. 2. Effect of UImus davidiana, Oldenlandia diffusa and their mixture on the colon weight in AOM/DSS-induced colitis-associated colonic neoplasms mice.

The groups refer to Fig. 1.

\# p<0.05 compared with normal group

* p<0.05 compared with control group

\section{2. 대장 조직의 형태학적 변화}

대장 점막 조직의 형태학적 변화를 관찰한 결과, Control군은 점막의 염증 세포와 림프구의 침윤이 심각하게 나타났으며, 곳곳의 이형성과 세포 붕괴 가 일어나 Normal군에 비해 대장 점막 조직의 심 각한 손상이 관찰되었다. 반면 UD군은 울혈성 반 응, $\mathrm{OD}$ 군은 염증세포의 침윤과 점막층 붕괴, $\mathrm{UD} 1+\mathrm{OD} 1$ 군은 점막 세포의 붕괴, UD2+OD1군은 점막 세포 붕괴 및 염증의 증상이 약간 있었으며, $\mathrm{UD} 1+\mathrm{OD} 2$ 군에서는 정상군과 거의 흡사한 대장 점막 조직의 유지 상태를 보였다. 모든 실험군은 Control군에 비해 Normal군과 비슷한 형태를 유지 하였는데, 특히 UD1+OD2군에서 가장 뚜렷한 효 과를 나타내었다(Fig. 3). 

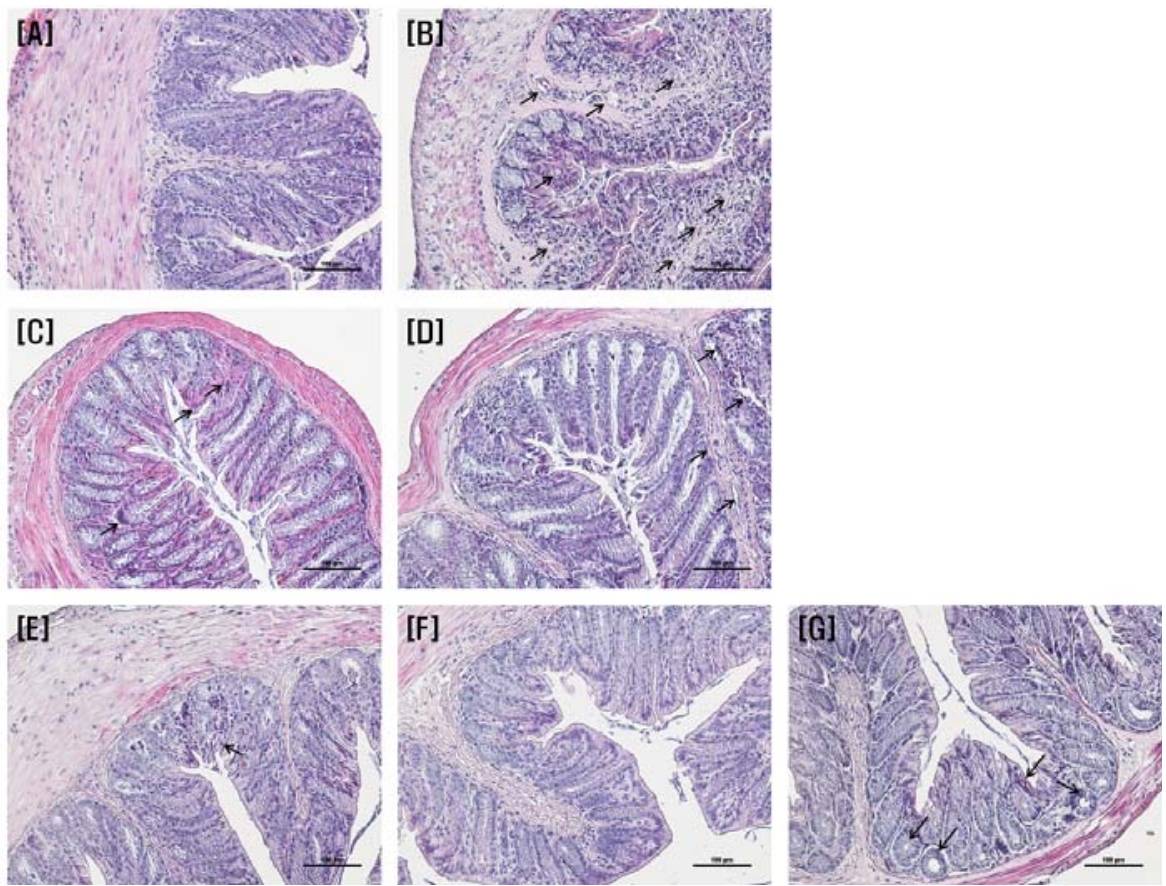

Fig. 3. Effect of UImus davidiana, Oldenlandia diffusa and their mixture on histopathologic change of colon mucous membrane tissue by light microscopy in AOM/DSS-induced colitis-associated colonic neoplasms mice.

[A] : Normal, [B] : Control, [C] : UD, [D] : OD, [E] : UD1+OD1, [F] : UD1+OD2, [G] : UD2+OD1

3. Serum pro-inflammatory cytokines 측정

1) TNF- $a$ 변화

TNF- $a$ 변화를 관찰한 결과, Normal군은 $4.7 \pm 0.27$ $\mathrm{pg} / \mathrm{ml}$, Control군은 $6.0 \pm 0.41 \mathrm{pg} / \mathrm{ml}$, Exp-A군은 $5.7 \pm$ $0.23 \mathrm{pg} / \mathrm{ml}$, Exp-B군은 $5.4 \pm 0.21 \mathrm{pg} / \mathrm{ml}, \mathrm{Exp}-\mathrm{C}$ 군은 $4.5 \pm 0.28 \mathrm{pg} / \mathrm{ml}, \mathrm{Exp}-\mathrm{D}$ 군은 $4.3 \pm 0.18 \mathrm{pg} / \mathrm{ml}$, Exp-E 군은 $3.6 \pm 0.17 \mathrm{pg} / \mathrm{ml}$ 를 나타내었다. Normal군에 비 하여 Control군은 유의한 증가를 나타내었고, Control 군에 비하여 $\mathrm{Exp}-\mathrm{C}$ 군, $\mathrm{Exp}-\mathrm{D}$ 군, $\mathrm{Exp}-\mathrm{E}$ 군은 유의 한 감소를 나타내었다(Fig. 4).

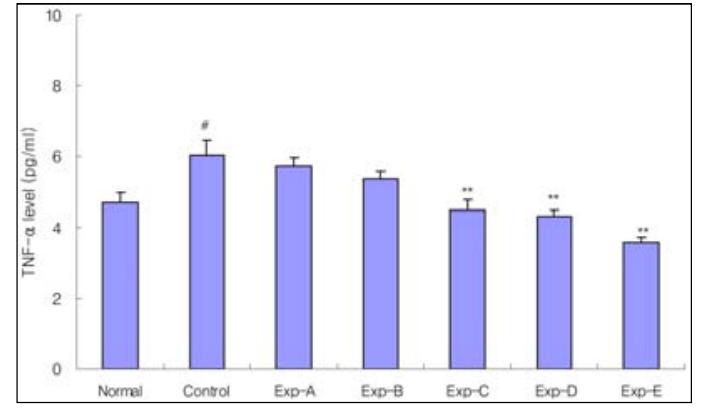

Fig. 4. Effect of Ulmus davidiana, Oldenlandia diffusa and their mixture on the TNF-a level in AOM/DSS-induced colitis-associated colonic neoplasms mice.

The groups refer to Fig. 1.

\# p<0.05 compared with normal group

** p<0.01 compared with control group 
2) $\mathrm{IL}-6$ 변화

IL-6 변화를 관찰한 결과, Normal군은 $10.7 \pm 0.83 \mathrm{pg} / \mathrm{ml}$, Control군은 $19.1 \pm 1.97 \mathrm{pg} / \mathrm{ml}$, Exp-A군은 17.8 \pm 3.92 $\mathrm{pg} / \mathrm{ml}, \quad \operatorname{Exp}-\mathrm{B}$ 군은 $15.9 \pm 0.97 \mathrm{pg} / \mathrm{ml}, \quad \operatorname{Exp}-\mathrm{C}$ 군은 $13.6 \pm 0.81 \mathrm{pg} / \mathrm{ml}$, Exp-D군은 $15.6 \pm 1.49 \mathrm{pg} / \mathrm{ml}$, Exp-E 군은 $15.5 \pm 0.99 \mathrm{pg} / \mathrm{ml}$ 를 나타내었다. Normal군에 비 하여 Control군은 유의한 증가를 나타내었고, Control 군에 비하여 $\mathrm{Exp}-\mathrm{C}$ 군은 유의한 감소를 나타내었 다(Fig. 5).

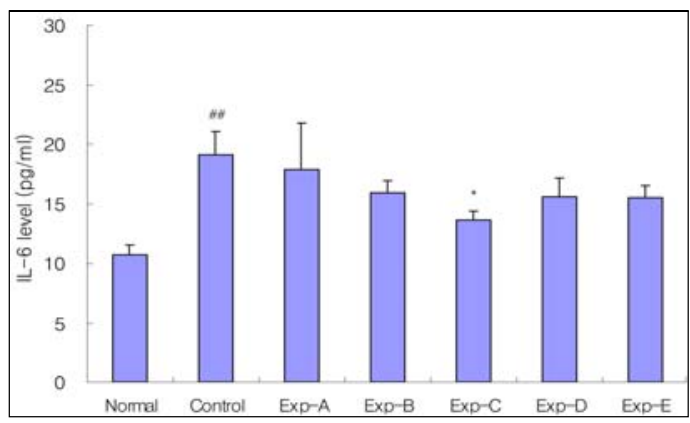

Fig. 5. Effect of Ulmus davidiana, Oldenlandia diffusa and their mixture on the $\mid \mathrm{L}-6$ level in AOM/DSS-induced colitis-associated colonic neoplasms mice.

The groups refer to Fig. 1.

\#\# $\mathrm{p}<0.01$ compared with normal group * p<0.05 compared with control group

\section{RT-PCR로 측정한 $\mathrm{Bax}, \mathrm{Bcl}-2, \mathrm{INF}-\mathrm{y}$ 발현 수준}

\section{1) $\mathrm{Bax}$ 변화}

$\mathrm{Bax}$ 변화를 관찰한 결과, Normal군은 $116.9 \pm 1.8$ 1030D, Control군은 86.9 \pm 3.2 1030D, Exp-A군은

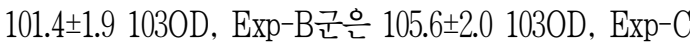

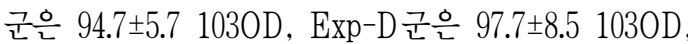

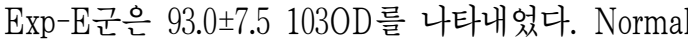
군에 비하여 Control군은 유의한 감소를 나타내었 고, Control군에 비하여 Exp-A군, Exp-B군은 유의 한 증가를 나타내었다(Fig. 6).

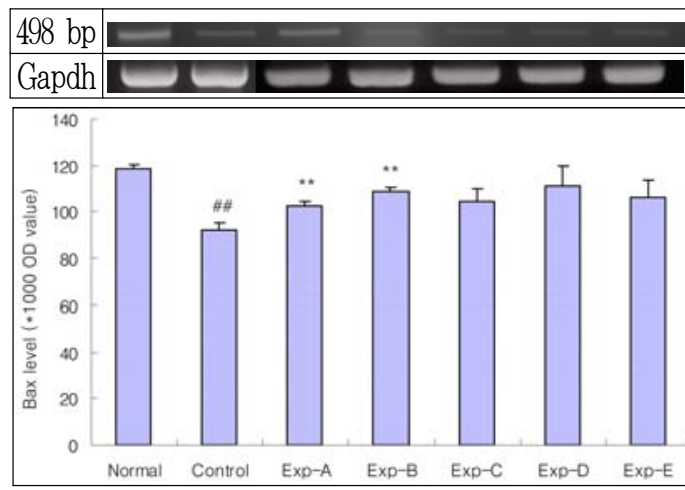

Fig. 6. Effect of Ulmus davidiana, Oldenlandia diffusa and their mixture on the Bax level in AOM/DSS-induced colitis-associated colonic neoplasms mice.

The groups refer to Fig. 1.

\#\# $\mathrm{p}<0.01$ compared with normal group

** $p<0.01$ compared with control group

2) $\mathrm{Bcl}-2$ 변화

$\mathrm{Bcl}-2$ 변화를 관찰한 결과, Normal군은 $99.3 \pm 2.9$ 1030D, Control군은 113.2 \pm 2.4 1030D, Exp-A군은 113.5 4.5 1030D, Exp-B군은 105.4 \pm 2.3 1030D, Exp-C

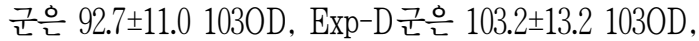
Exp-E군은 73.8 $\pm 5.41030 \mathrm{D}$ 를 나타내었다. Normal 군에 비하여 Control군은 유의한 증가를 나타내었 고, Control군에 비하여 Exp-E군은 유의한 감소를 나타내었다(Fig. 7).

3) INF- $\gamma$ 변화

INF- $\gamma$ 변화를 관찰한 결과, Normal군은 $99.6 \pm 4.6$ 1030D, Control군은 127.8 4.2 1030D, Exp-A군은

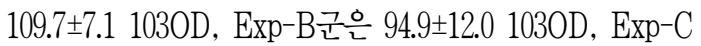

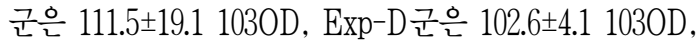
Exp-E군은 116.3 $\pm 5.01030 \mathrm{D}$ 를 나타내었다. Normal 군에 비하여 Control군은 유의한 증가를 나타내었 고, Control군에 비하여 Exp-B군, Exp-D군은 유의 한 감소를 나타내었다(Fig. 8). 


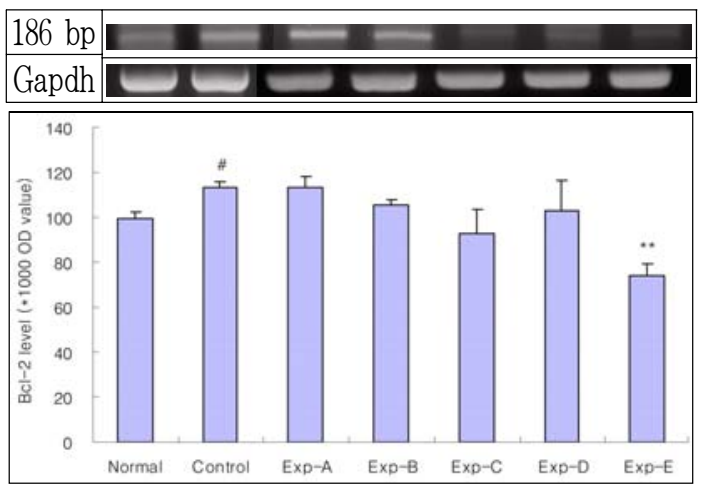

Fig. 7. Effect of Ulmus davidiana, Oldenlandia diffusa and their mixture on the Bcl-2 level in AOM/DSS-induced colitis-associated colonic neoplasms mice.

The groups refer to Fig. 1.

\# $\mathrm{p}<0.05$ compared with normal group

** $p<0.01$ compared with control group

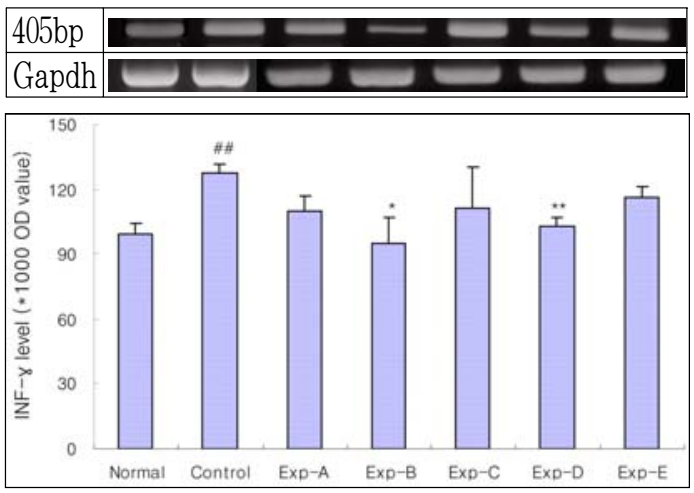

Fig. 8. Effect of Ulmus davidiana, Oldenlandia diffusa and their mixture on the INF-y level in AOM/DSS-induced colitis-associated colonic neoplasms mice.

The groups refer to Fig. 1.

\#\# $\mathrm{p}<0.01$ compared with normal group

* $p<0.05,{ }^{* *} p<0.01$ compared with control group

\section{IV. 고 찰}

암은 심뇌혈관 질환과 함께 사망원인의 1,2 위를 차지하며, 우리나라에서는 1998년 이래로 전체 사 망원인 가운데 1 위를 점유하게 되면서 사회적으로
나 의학적으로 중요한 관심사로 대두하게 되었다 ${ }^{11}$. 암의 치료방법 중 최근에는 환자의 면역체계를 강 화시켜서 암을 극복할 수 있게 하는 면역요법이 각광받게 되었고 ${ }^{12}$, 이에 따라 암에 관한 실험 및 임상적인 연구도 면역능력을 증강시키는 방법으로 항암 효과를 극대화할 수 있는 약물에 대한 연구 들이 보고되고 있다 ${ }^{13.14}$.

한의학에서도 암 치료시에 氣血의 虛實정도에 따라서 祛邪하되 正氣를 손상시키지 않는 扶正祛 邪法을 사용하는데, 실제로 방사선 및 화학요법에 한약을 병용하면 인체조직을 손상시키는 부작용을 감소시키고 면역기능과 항암작용은 강화시키므로 치료율을 높여준다 ${ }^{15}$. 한의계의 항암 연구는 약재의 효능분류상 주로 扶正法보다는 祛邪法 위주로 하 여 보고되었는데, 따라서 淸熱解毒- 祛濕利水之劑 와 같은 祛邪氣劑를 쓰는 경우 면역반응을 방해하 는 요소를 제거하고 인체의 생리활동을 회복시킴 으로써 항암 및 면역력 증강 효과가 나타나는 것 으로 볼 수 있다 ${ }^{16}$.

榆根皮( Ulmus davidiana)는 약리성분 실험상 $\beta$-sitosterol 은 항암 및 항염효과가, friedelin, epifriedelanol 및 taraxerol은 진통효과가 인정되었으며 ${ }^{17}$, 유근피 추 출물로부터 단백다당체를 분리하여 성분분석한 실 험에서 glucuronic acid, rhamnose, arabinose, glucose 등의 당 성분이 면역증강에 의한 항암 효과를 나 타내는 것으로 검증되었다 ${ }^{18}$. 이 밖에 최근 생리활 성 연구상 유의적으로 높은 전자공여능과 아질산 염 소거능 및 유방암 세포 증식 억제능이 보고되 었다 ${ }^{19}$.

白花蛇舌草(Oldenlandia diffusa)의 약리성분 중 ursolic acid는 항암활성을 나타내는 주요성분으로 배당체인 asperuloside와 병용시 항암 및 항전이 효 과가 증가된다고 검증되었고 ${ }^{20}, \beta$-sitosterol은 발암 원으로 유발된 쥐의 대장암을 억제하고, 항염증 효 과도 있는 것으로 알려져 있다 ${ }^{21.22}$. 최근 백화사설 초 연구들을 보면, 진 등 $^{23}$ 이 세포주기 억제와 세포 고사 유발에 의한 유방암 세포의 성장 억제 및 생 
존율 감소 현상을, 노 등 ${ }^{24}$ 이 HL-60 암세포에서 세 포자멸사 신호전달기전인 caspase- 3 를 활성화시키 고 colony 형성을 저해시킨다고 보고하였다.

유근피와 백화사설초에 관한 각 단일 연구들은 상기와 같이 진행되어 그 항암 효과가 보고되고 있으나, 두 약재의 배합물이 가지는 항암 작용에 관한 연구는 아직 접하지 못하였다. 그리고 보건복 지부 통계상 2012년도 기준 암 발생 현황이 갑상선 암, 위암에 이어 대장암이 세 번째로 많이 발생하 고 있고 ${ }^{25}$, 그 유발 요인이 서구형 식생활 변화에 따른 환경적 요인과 염증성 질환 및 대장용종과 같은 유전적 요인이라는 것에 착안하여 ${ }^{26,27}$, 두 약 물의 단일 및 배합제제의 염증 관련 대장암에 대 한 항암 및 항염 효과를 알아보고자 AOM/DSS로 유발된 대장암 mice의 대장 길이 및 무게, 대장 조 직의 병리학적 변화를 관찰하고, 염증매개인자인 $\mathrm{TNF}-a$ 와 $\mathrm{IL}-6$ 의 변화, $\mathrm{RT}-\mathrm{PCR}$ 로 측정한 $\mathrm{Bax}$, $\mathrm{Bcl}-2, \mathrm{INF}-\mathrm{\gamma}$ 의 발현도 변화를 조사하여 다음과 같은 결과를 얻었다.

궤양성 대장암이 발생하면 대장의 길이는 감소 하는 경향을, 염증 및 종양으로 조직이 경직화되어 대장의 무게는 증가하는 경향을 보인다 ${ }^{28}$. 따라서 대장의 길이는 짧고, 무게는 무거울수록 궤양성 대 장암이 더 유발된 것으로 볼 수 있다. 본 연구에서 대장 길이 측정 결과 Normal군에 비하여 Control 군은 유의한 감소를 나타내었고, Control군에 비하 여 $\mathrm{OD}$ 군, $\mathrm{UD} 1+\mathrm{OD} 2$ 군, UD2+OD1군은 유의한 증 가를 나타내어 대장 길이가 회복되는 대장암 억제 효과를 확인할 수 있었다. 대장 무게 측정 결과 Normal군에 비하여 Control군은 유의한 증가를 나 타내었고, Control군에 비하여 OD군, UD1+OD2군 에서 유의성 있는 감소를 나타내었다. 이 등 ${ }^{29}$ 은 길 경탕에 백화사설초를 가미한 처방이 길경탕 원방 보다 $\mathrm{C} 57 \mathrm{BL} / 6$ 생쥐의 피하에 증식된 흑색종의 무 게를 대조군에 비해 더 유의성 있게 억제시켰다고 보고하였는데, 본 연구에서 단독군에서는 백화사설 초군, 배합군에서는 백화사설초가 가장 고농도로
투여된 군에서 대장암의 무게가 감소하였기에 이 와 부합되는 결과로 사료된다.

$\mathrm{AOM} / \mathrm{DSS}$ 로 유발된 대장암 mice의 대장 조직 의 형태학적 변화를 관찰한 결과, Control군은 점 막의 염증 세포와 림프구의 침윤, 곳곳의 이형성과 세포 붕괴가 보였다. 모든 실험군은 Control군에 비해 Normal군과 비교적 비슷한 세포 형태를 유지 하였는데, 단독군들에 비해 배합군들에서 장 상피 세포의 변형이 약하게 나타나 더욱 우수한 세포 보존 상태가 관찰되었으며, 특히 UD1+OD2군은 정상군과 거의 흡사한 대장 점막 조직 상태를 보 여 가장 뛰어난 염증세포의 침윤 억제 효과를 나 타내었다.

이 등 ${ }^{29}$ 은 Sarcoma 180 복강암 이식 생쥐에 대한 간장의 조직 변화에 있어서 길경탕에 백화사설초 를 가미한 처방이 원방보다 대조군에 비해 간문맥 주위로의 암세포 침윤이 매우 적었다고 보고하였 고, 진 등 ${ }^{23}$ 은 유방암 세포의 형태 변화에 있어서 백화사설초와 절패모를 복합처리한 경우 각각 단 독처리군에 비하여 약한 형태학적 변화를 나타내 었다고 보고하였는데, 본 연구에서 유근피와 백화 사설초 배합투여군이 각각 단독투여군보다 세포의 변형이 약하게 나타났고, 특히 백화사설초가 가장 고농도로 처리된 배합투여군에서 가장 우수한 점 막 조직 유지 상태를 보인 것은 이와 부합되는 결 과가 발현된 것으로 사료된다.

염증성 장질환은 장 점막의 염증 관련 면역 세 포가 과잉 활동해서 발생하는데, 이는 TNF-a, IL- 6 와 같은 대표적인 염증성 cytokine의 수준을 높이고, 따라서 이러한 pro-inflammatory cytokines은 염증 이 생긴 대장 조직이나 대장암으로 발전한 경우 높 은 수준으로 나타나게 된다 ${ }^{30.31}$.

두 약물의 단일 및 배합제제의 항암 및 항염 효 과를 알아보고자 AOM/DSS로 유발된 대장암 mice 의 pro-inflammatory cytokines 수준 측정 결과, TNF- $a$ 와 IL-6 모두 Normal군에 비하여 Control군 에서 유의한 증가를 나타내었고, TNF- $a$ 는 Control 
군에 비하여 모든 배합투여군에서 유의성 있는 감소 를 보였고, IL-6는 Control군에 비하여 UD1+0D1군 에서 유의한 감소를 나타내었다.

마우스 대식세포주인 RAW 264.7 cell을 이용한 연구에서 김 등른 interferon-gamma에 의해 유도 되는 TNF- $a$ 의 분비가 유근피 물 추출물에 의해 억제된다고, 정 ${ }^{33}$ 은 유근피 에틸아세테이트 분획물 이 LPS로 유도된 IL-6의 발현을 농도 의존적으로 감소시켰다고 보고하였다. 또한 조 ${ }^{34}$ 는 마우스 복강 대식세포에서 백화사설초가 LPS와 INF- $x$ 로 자극 한 TNF-a와 IL-6의 생산을 억제시킨다는 것을 확 인하여 염증반응을 조절하는 작용이 효과적이라고 보고하였다. 본 연구에서 유근피와 백화사설초를 배합한 제제가 TNF-a와 IL-6 수준을 유의성 있게 감소시킨 결과도 이와 부합된다고 할 수 있으며, 두 전염증성 사이토카인 모두 단독군보다 배합군에 서 더 감소의 경향을 보였는데, TNF-a 경우 UD2+OD1 군에서, IL-6 경우 UD1+0D1군에서 가장 낮은 수 치로 유의한 감소가 나타나 염증성 장질환 및 염 증 관련 대장암의 발생을 효과적으로 억제시킴을 확인할 수 있었다.

두 약물의 단일 및 배합제제의 항암 및 항염 효 과를 알아보고자 AOM/DSS로 유발된 대장암 mice 의 대장 조직에서 $\mathrm{RT}-\mathrm{PCR}$ 로 측정한 $\mathrm{Bax}, \mathrm{Bcl}-2$, $\mathrm{INF}-\gamma$ 의 mRNA 발현도 변화를 관찰하였다. $\mathrm{Bax}$ 는 Normal군에 비하여 Control군에서 유의한 감소 를 나타내었고, Control군에 비하여 유근피 및 백 화사설초 단독군들에서 유의한 증가를 보였으며, $\mathrm{Bcl} 2$ 는 Normal군에 비하여 Control군에서 유의한 증가를 나타내었고, Control군에 비하여 UD2+OD1 군에서 유의한 감소를 나타내었다. 그리고 INF-8 는 Normal군에 비하여 Control군은 유의한 증가를 나타내었고, Control군에 비하여 OD군과 UD1+OD2 군에서 유의성 있는 발현량 감소를 나타내었다.

Apoptosis는 세포의 계획된 자멸사를 말하는 것 으로, 항상성 유지를 위해서 일어나는 생리적인 세 포사멸로, 이 과정이 원활하게 이루어지지 않으면
세포의 성장이 비정상적으로 증식되어 결국 암이 발생하게 되므로, apoptosis가 활성화되면 암 발병 이 효과적으로 억제된다고 볼 수 있다 ${ }^{35.36}$. 세포사 멸에 중요한 역할을 하는 Bcl-2 family는 apoptosis 경로 중 intrinsic pathway인 mitochondrial pathway 에 작용하는 단백질로 $\mathrm{Bcl}-2$ 로 대표되는 anti-apoptotic members와 Bax로 대표되는 pro-apoptotic members 로 나뉜다 ${ }^{37.38}$. 세포 내부에서 사멸신호가 들어오면 $\mathrm{Bax}$ 는 미토콘드리아 막을 탈분극화하여 cytochrome C 등을 밖으로 유출시켜 apoptosis를 촉진시키는 반면, Bcl-2는 미토콘드리아 막의 탈분극화를 억제 하여 cytochrome C 등의 유출을 저해시키므로, 이 두 단백질은 서로 상호적으로 관계하면서 세포사 멸을 조절하게 된다 ${ }^{39,40}$.

노 등 ${ }^{24}$ 과 김 등 $^{41}$ 의 연구에서 백화사설초 메탄올 추출물이 $\mathrm{Bcl}-2$ 의 분해를 촉진, $\mathrm{Bax}$ 의 발현을 증가 시키는 과정을 통해 세포고사 실행인자를 활성화 시킴으로써 HL-60 암세포의 사멸을 유도한다는 결과가 도출되었고, 박 등 ${ }^{42}$ 은 유근피 추출물이 mitochondrial apoptosis pathway인 Bcl-2의 발현을 억제시켜 HT-29 대장암 세포의 사멸을 유도한다 고 보고하였다. 본 연구에서도 이와 부합되는 결과 로 $\mathrm{Bax}$ 는 단독군들에서 유의한 증가를, $\mathrm{Bcl}-2$ 는 $\mathrm{UD} 2+\mathrm{OD} 1$ 군에서 유의한 감소를 나타내었으며, 이 는 유근피 및 백화사설초가 $\mathrm{AOM} / \mathrm{DSS}$ 로 유발된 대장암 mice에 대해 apoptosis를 유도하여 항암활 성을 나타낸 것으로 대장암의 발생 및 진행을 억 제하는 것으로 사료된다.

INF- 8 는 pro-inflammatory cytokine 중의 하나 로 염증세포를 활성화시키는 작용을 하는데, 과잉 발현시에는 조직의 종창 및 기능장애가 나타나며, 악성종양 및 자가면역질환 등에 노출되게 된다 ${ }^{43}$. 본 연구에서 INF-8의 발현도는 모든 실험군이 Control군에 비하여 감소의 경향을 보였는데, 단독 군 비교시 유근피보다는 백화사설초에서, 배합군 비교시 백화사설초가 가장 고농도로 투여된 제제 에서 유의한 발현량 감소를 확인할 수 있었다. 이에 
$\mathrm{OD}$ 군과 $\mathrm{UD} 1+\mathrm{OD} 2$ 군이 염증 관련 대장암 유발의 억제 및 예방 효과가 우수하다고 볼 수 있겠다.

이상 본 실험의 성적들을 종합해 보면 두 약물 의 단일 및 배합제제가 AOM/DSS로 유발된 대장 암 mice에 미치는 영향을 살펴본 결과, 대장 길이 와 무게는 공통적으로 $\mathrm{OD}$ 군과 UD1+OD2군에서 궤양성 대장암을 덜 유발시키는 유의성 있는 결과 를 나타내었고, 대장 조직의 병리학적 변화는 단독 군들에 비해 배합군들에서 장 상피세포의 변형이 약하게 나타났는데, 특히 UD1+OD2군에서 가장 뛰어난 염증세포의 침윤 억제 효과를 나타내었다. Pro-inflammatory cytokines 중 TNF- $\alpha$ 는 모든 배 합군에서 유의성 있는 감소를, IL-6는 UD1+OD1 군에서 유의한 감소를 나타내었으며, $\mathrm{mRNA}$ 발현 도를 관찰한 결과 $\mathrm{Bax}$ 는 모든 단독군에서 유의한 증가를, $\mathrm{Bcl}-2$ 는 $\mathrm{UD} 2+0 \mathrm{D} 1$ 군에서 유의한 감소를, INF- 8 는 OD군과 UD1+0D2군에서 유의성 있는 감소를 나타내었다.

위와 같은 결과로 보건대, 유근피와 백화사설초 의 단일 및 배합제제가 $\mathrm{AOM} / \mathrm{DSS}$ 로 유발된 대장 암 mice에서 염증세포의 침윤을 억제하여 대장 조 직의 손상을 보호하고, TNF-a, IL-6, INF- 8 와 같 은 염증성 사이토카인의 활성을 유의성 있게 감소 시키며, $\mathrm{Bax}$ 의 발현은 증가, $\mathrm{Bcl}-2$ 의 발현은 저해 하여 apoptosis를 유도함으로써 항암 효과를 나타 내었으므로 이에 염증성 장질환 및 염증 관련 대 장암의 발생 및 진행을 효과적으로 억제시키는 작 용이 있을 것으로 판단된다. 따라서 임상에서 항암 치료시 유근피와 백화사설초를 활용할 수 있으리 라 사료되며, 본 실험에서 두 약재를 단독 및 배합 투여해서 사용했을 때의 항암효능 결과가 각 항목 별로 차이가 있었으므로, 향후 이와 관련된 추가적 인 연구가 요구된다. 아울러 두 약물의 약리성분 중 공통물질인 $\beta$-sitosterol 및 유근피의 당 성분과 백화사설초의 ursolic acid, asperuloside와 같은 항 암 효과를 나타내는 지표물질에 관한 더욱 구체적 인 연구가 필요할 것으로 사료된다.

\section{V. 결 론}

유근피와 백화사설초 및 유근피와 백화사설초 배합제제가 가지는 항암 및 항염 작용을 알아보고 자, $\mathrm{AOM} / \mathrm{DSS}$ 로 유발된 대장암 mice의 대장 길이 및 무게, 대장 조직의 병리학적 변화, 염증매개인 자인 $\mathrm{TNF}-a$ 와 $\mathrm{IL}-6$ 의 변화, $\mathrm{RT}-\mathrm{PCR}$ 로 측정한 $\mathrm{Bax}, \mathrm{Bcl}-2, \mathrm{INF}-\mathrm{y}$ 의 발현도를 관찰한 바 아래와 같은 결론을 얻었다.

1. 대장 길이 변화는 $\mathrm{OD}$ 군, $\mathrm{UD} 1+\mathrm{OD} 2$ 군, $\mathrm{UD} 2+\mathrm{OD} 1$ 군에서 유의한 증가를 보였고, 대장 무게 변화는 $\mathrm{OD}$ 군, $\mathrm{UD} 1+\mathrm{OD} 2$ 군에서 유의한 감소를 나타내 었으며, 대장 조직의 병리학적 변화는 단독군에 비해 배합군에서 장 상피세포의 변형이 약하게 나타났는데, 특히 UD1+0D2군에서 가장 우수 한 염증세포 침윤 억제 효과를 나타내었다.

2. 염증매개인자인 pro-inflammatory cytokines 수 준 측정 결과 $\mathrm{TNF}-\mathrm{a}$ 는 모든 배합투여군에서 유 의성 있는 감소를 나타내었고, IL-6는 UD1+OD1 군에서 유의성 있는 감소를 나타내었다.

3. RT-PCR로 측정한 mRNA 발현도 변화에 있어 서 $\mathrm{Bax}$ 는 모든 단독군에서 유의하게 증가하고 $\mathrm{Bcl}-2$ 는 UD2+OD1군에서 유의하게 감소하여 apoptosis를 활성화시킴으로써 항암효과를 나타 내었고, INF- 8 는 OD군과 UD1+OD2군에서 유 의성 있는 발현량 감소를 나타내었다.

이상의 결과를 종합해 볼 때 유근피와 백화사설 초의 단일 및 배합제제가 염증성 장질환 및 염증 관련 대장암의 발생 및 진행을 억제하는 효과가 있는 것으로 사료되며, 임상에서 항암 치료시 두 약재의 활용가능성이 높을 것으로 기대된다. 다만, 단독 및 배합투여군의 구체적인 항암활성 차이에 관한 심도 있는 후속 연구가 필요할 것으로 사료 된다. 


\section{참고문헌}

1. Park JG, Park CI, Kim NG. Oncology. Seoul: Iljogak; 2003, p. 128-34, 160.

2. Maduro JH, Pras E, Willemse PH, de Vries EG. Acute and long-term toxicity following radio therapy alone or in combination with chemotherapy for locally advanced cervial cancer. Cancer Treat Rev 2003;29(6):471-88.

3. Suh N, Luyengi L, Fong HHS, Kinghorn AD, Pezzuto JM. Discovery of Natural Product Chemopreventive Agents Utilizing HL-60 Cell Differentiation as a Model. Anticancer Res 1995; $15(2): 233-9$.

4. Kang BS, Go UC, Kim GY, Kim SH, No SH, Park YG, et al. Bonchohak. Seoul: Yeonglimsa; 1991, p. 418-9.

5. Kim HS, Cho JH, Lee JM, Lee CH, Jang JB, Lee KS. Experimental Studies on Antimetastatic and Immunomodulating Effects of Ulmus davidiana. The Journal Of Oriental Gynecology 2010;23(1) $: 1-11$.

6. Han SI, Choi SD, Park YK, Kim GS, Kang BK. A Study on Antitumor Effect and Mechanism of Cortex ulmi pumilae Water Extract on HepG2 Hepatoma cell. Korean J Oriental Int Med 2000; 21(2) :259-66.

7. Shin MG. Imsang-bonchohak. Seoul: Yeonglimsa; 2002, p. 569-70.

8. Lee SJ, Gim HJ, Shim JH, Park HS, Kim BJ. Anti-Cancer Effects of Oldenlandia diffusa extract on WiDr human colorectal adenocarcinoma cells. Herbal Formula Science 2015:23(1):101-10.

9. Park JB, Sung NI, Lee JY, Hur IK, Kim SM, Nam JH, et al. Apoptotic Effect of Hedyotis Diffusa in Gastric Cancer Cell Lines. The DongGuk Journal of Medicine 2006;13(2):64-72.
10. Choi YH. Research techniques for the cell cycle study. Exp Mol Med 2001;33:15-36.

11. Choi SH. Dongui-oncology. Seoul: Haenglim publishing company; 1995, p. 13.

12. A medical college of Seoul National University. Immunology. Seoul: Seoul National University publishing department; 1993, p. 303-9.

13. Jeong JW, Choi YH, Park C. Induction of Apoptosis by Ethanol Extract of Cnidium officinale in Human Leukemia U937 Cells through Activation of AMPK. J Life Sci 2015;25(11) :1255-64.

14. Joung BB, Kim YC. Study on Anti-Cancer Effects of Rhus Verniciflua Stokes Extracted with Sterile Distilled Water on Two Cholangiocarcinoma Cell Lines, SNU-1079 and SNU-1196. Korean $J$ Oriental Int Med 2015;36(1):1-12.

15. Moon G, Jung BH, Kim BJ. Cancer, shared treatment of oriental and western medicine. Iksan: Wonkwang University publishing department; 1999, p. 253-7, 461-6.

16. Kim HA, IM SW, Lee WC. A study of the tendency of anti-cancer experimental study using herbal medicines. $J$ of Kor Traditional Oncology 1998;4(1):211-32.

17. Hong ND, Kim NJ, No YS, Kim JS. Studies on the Pharmacological Activities and Constituents of Ulmi Cortex. Korean Journal of Pharmacognosy 1990;21(3):245.

18. Yang YL, Kim YJ, Kim KH, Oh EG. Separation of Glycoprotein and its Anticancer Immunostimulating Activity from Dried Barks of Slippery Elm(Ulmus parvifolia). KSBB Journal 2001;16(6):547-53.

19. Jeong KY, Kim ML. Physiological Activities of Ulmus pumila L. Extracts. Korean $J$ Food Preserv 2012;19(1) :104-9.

20. Kim SH, Song GY, Ryu SY. Antitumor and 
antimetastatic activities of ursolic acid and asperuloside. JPPKM 1999;13(1):65-75.

21. Raicht RF, Cohen BI, Fazzini EP, Sarwal AN, Takahashi M. Protective effect of plant sterols against chemically induced colon tumors in rats. Cancer Res 1980;40:403-5.

22. Gupta MB, Nath R, Srivastava N, Shanker K, Kishor K, Bhargava KP. Anti-inflammatory and antipyretic activities of beta-sitosterol. Planta Med 1980;39(2):157-63.

23. Jin MH, Park SY, Kang YG, Shim WS, Hur HS, Hong SH, et al. Anti-cancer Effects of Oldenlandia diffusa, Cremastra appendiculata and Fritillaria thunbergii on MDA-MB-231 Human Breast Cancer Cells. Korean J Oriental Int Med 2014;35(2):133-44.

24. No HJ, Moon G, Moon SJ, Won JH, Moon YH, Park RG. Study of Hedyotis Diffusa Methanol Extract on Anti-tumoral Effect and Mechanism. $J$ of Kor Traditional Oncology 2000; 6(1) :81-97.

25. Jung KW, Won YJ, Kong HJ, Oh CM, Cho HS, Lee DH, et al. Cancer Statistics in Korea: Incidence, Mortality, Survival, and Prevalence in 2012. Cancer Res Treat 2015;47(2):127-41.

26. Singh J, Hamid R, Reddy BS. Dietary Fat and Colon Cancer: Modulating Effect of Types and Amount of Dietary Fat on ras-p21 Function during Promotion and Progression Stages of Colon Cancer. Cancer Res 1997:57(2):253-8.

27. Kang HT, Lee SH, Kim SY, Kim MS, Shin WC, Sohn HY, et al. Anti-proliferative Activities of Solvent Fractions of Lees Extracts in Human Colorectal HCT116 Cells. J Life Sci 2014;24(9) :967-72.

28. Li H, Wu WK, Li ZJ, Chan KM, Wong CC, Ye CG, et al. 2,3,4,4,5-Pentamethoxy-trans-stilbene, a resveratrol derivative, inhibits colitis-associated colorectal carcinogenesis in mice. British $J$ pharmacology 2010;160(6):1352-61.

29. Lee GH, Kim SH, Song HJ. Study on Antitumor Effect and Immune Response of Kilkyungtang and Kamikilkyungtang. JPPKM 1996;10(1):105-19.

30. Lee YJ, Kim JE, Kwak MH, Go J, Son HJ, Kim DS. Toxicity of fermented soybean product (cheonggukjang) manufactured by mixed culture of Bacillus subtilis MC31 and Lactobacillus sakei 383 on liver and kidney of ICR mice. Lab Anim Res 2014:30:54-63.

31. Hendrickson BA, Gokhale R, Cho JH. Clinical aspects and pathophysiology of inflammatory bowel disease. Clin Microbiol Rev 2002;15:79-94.

32. Kim HM, Lee SO, Lee EH. The Nitric Oxide -Producing Properties of Ulmi Radicis Cortex Extract. Immunopharmacol Immunotoxicol 1999; 21(2):295-306.

33. Jung HJ. Anti-atherosclerosis effects of Ulmi Cortex extracts by anti-oxidant, anti-platelet, anti-inflammatory effects. Doctoral thesis of Dongguk University Graduate School 2010.

34. Jo YM. Anti-inflammatory Activity of Oledenlandia Diffusa through the Inhibition of NF-kB activation in Mouse Peritoneal Macrophage. Master's thesis of Wonkwang University Graduate School 2008.

35. Korsmeyer SJ. Regulators of cell death. Trends Genet 1995:11(3):101.

36. Hengartner MO. The biochemistry of apoptosis. Nature 2000;407:770-6.

37. Debatin KM. Apoptosis pathways in cancer and cancer therapy. Cancer Immunol Immunother $2004 ; 53(3): 153-9$.

38. Gross A, McDonnell JM, Korsmeyer SJ. BCL-2 family members and the mitochondria in apoptosis. Genes Dev 1999;13(15):1899-911. 
39. Li Z, Xu X, Huang Y, Ding L, Wang Z, Yu G, et al. Swainsonine activates mitochondria-mediated apoptotic pathway in human lung cancer A549 cells and retards the growth of lung cancer xenografts. Int J Biol Sci 2012;8(3):394-405.

40. Fesik SW. Insights into programmed cell death through structural biology. Cell 2000;103(2): $273-82$.

41. Kim IJ, Lee GU, So HS, Park RK, Won JH, Moon G, et al. Study on caspases activation change of HL-60 cell apoptosis by hedyotis diffusa's methanol extract. The Journal of Traditional Korean Medicine 2000;10(1):255-69. 42. Park YK, Jung SJ, Jang TJ, Lee JH. Effects of Ulmi cortex extract on cell apoptosis in HT-29 human colon cancer cells. Kor J Herbology 2006; 21(4):51-8.

43. Rabson A, Roitt IM, Delves PJ. Really essential medical immunology. Oxford, UK: Blackwell publishing Ltd; 2005, p. 1-14. 